Invited submission to Historical Materialism, Mini-Symposium on Massimiliano Tomba's Marx's Temporalities, June 2014

\title{
Out of Sync
}

\section{Tomba's Marx and the Problem of a Multi-layered Temporal Dialectic}

\section{Peter Osborne}

\begin{abstract}
This piece reconstructs and reflects upon the terms of the theoretical projection underlying Max Tomba's book, Marx's Temporalities, with particular reference to his use of the concepts of multiple temporalities (Enst Bloch) and temporal layers (Bloch and Reinhart Koselleck). Tomba's use of these concepts, it is argued, productively relocates Marx's writings within the framework of the $20^{\text {th }}$-century philosophy of time. However, Tomba's dependence upon received versions of these concepts, untransformed, reproduces theoretical problems implicit within them, which have been intensified by recent developments within global capital. The application of these concepts to an understanding of the historical present, understood as a situation of globally disjunctive contemporaranity, is seen to be, in part, vitiated by their embeddness within an increasingly exhausted past.
\end{abstract}

\section{Keywords}

Time; multiple temporalites; temporal layers; syncronization; global contemporaneity; Marx; Bloch; Koselleck; hegemony; occasion of intervention.

Marx's Temporalities is a book that opens a new horizon of expectation with its title alone. This is not just 'Time in Marx', ${ }^{1}$ but Marx's temporalities - qualitative, plural and experiential, as well as 'objective' or imposed: 'temporalities of labour', 'temporalities of capital' and 'historical counter-temporalities of the class struggle', to name the three main sets at stake in this work. ${ }^{2}$ With the phrase 'Marx's temporalities', Tomba not only locates Marx's writings within the ambit of the philosophy of time, he places their interpretation firmly within the field of its twentieth-century developments, and post-Heideggerian thought about time in particular (although it is not clear that the latter is self-consciously so, since there is 
no reference to Heidegger). ${ }^{3}$ The idea that 'Capital is a treatise on time, not only on stolen time, but also on its transformation and ontologisation' ${ }^{4}$ opens up an interpretative horizon that is explored here primarily in the wake of the writings of Ernst Bloch, Walter Benjamin and Reinhardt Koselleck. (The Bergsonian moment in Lukàcs's History and Class Consciousness, so important for Bloch and Benjamin alike, is absent.)

The first two of these three figures were anti-Heideggerian Marxists, who sought to occupy the space opened up by the early Heidegger's existentialism on quite different philosophical and political terms (in part, provided by Christian and mystical Jewish messianism, respectively); the third, is a politically ambivalent (at best) student of Heidegger and Gadamer, who transformed the hermeneutical side of their ontology into a novel brand of historical semantics, as the methodological basis for a new kind of conceptual history. Bloch's multiversum, conceiving of differences between historical temporalities as 'a polyphony of a unity'; Benjmain's novum exploding in the clash between different times; Koselleck's generalization of Bloch's idea of multiple layers of time (Zeitschichten) - these are the sources that come together in Tomba's book to structure readings of Marx that aim to think 'temporal diversities' politically. The world market is a mechanism for synchronising temporalities, Tomba argues, so the problem becomes how 'to think the temporalities that are asynchronic in relation to the process of synchronization'. 5 This is an extremely productive formulation. However, the way in which Tomba responds to it is, ironically, overshadowed by what Bloch called the (arguably) 'genuine' pastness of certain of the theoretical elements upon which he draws.

In approaching Marx's writings, and Capital in particular, in this way, Tomba's book points beyond the more straightforward combinations of philological and 
categorial analysis characteristic of the recent revival of Marx Studies in Historical Materialism, to suggest a thoroughly 'temporalized' Marx, directly relevant to the politics of global capitalism and - one would have thought, although once again the theme is oddly absent - crisis, today. At the level of theory, however, Tomba's book remains primarily only suggestive. The details of the readings are precise, illuminating and often provocative: in emphasising the theoretical break represented by the manuscripts of 1861-3, in relation to the Grundrisse, for example; and the importance of Marx's engagement with the Russian populists and his ethnographical notebooks - all 'late' writings. But there is no theoretical construction, or even reconstruction, sensu stricto here. Formally, the book's three chapters and two appendices function as a constellation of five essays, each focused on a different body of Marx's texts. To get to the more enduring heart of the contribution of Marx's Temporalities, therefore, one must reconstruct for oneself the terms of its underlying theoretical projection, in order to draw out its implications, possibilities and limitations.

There are two main issues at stake: first, the theorisation of the multiplicity of social temporalities within contemporary capitalism, via the appropriation of the idea of a 'multi-layered temporal dialectic' to be found in the writings of Bloch and Koselleck; and second, the articulation of the unity of these temporalities through the concept of synchronization, with respect to (i) the world market and (ii) the experience of divergent or conflicting temporalities as the "political occasion of an intervention'. 6

We must start, therefore, elsewhere than Tomba himself: with a consideration of Bloch's famous concept of 'non-sametimeliness' (Ungleichzeitigkeit) and the 'obligation to its dialectic' set out in the 'Summary Transition' of that name ('Non- 
sametimeliness and the Obligation to its Dialectic'), dated May 1932, in his 1935 Erbschaft dieser Zeit - Inheritance of This Time. 'Non-sametimeliness' (as I shall translate Ungleichzeitigkeit, in an awkwardly literal manner, for reasons that will become apparent shortly) is Bloch's register of the paradoxical multiplicity of historical temporalities within a common present, construed according to an orthodox materialist conception of historical forms, calibrated by a series of modes of production and their constitutive class relations. It derives from Marx's own idea of 'unequal development'. This idea is combined uncertainly by Tomba with that of a 'plurality' of capitalistic social times, of which the main ones are those 'temporalities of capital' that Tomba derives from Tombazos's commentary on 'categories of time in Marx's Capital'. I say 'uncertainly', since the 'temporalities of capital' in the title of chapter 3 remain unreflected with the 'layered historiography' in its appendix, on Marx's chapter on 'so-called primitive accumulation'. The theoretical problem raised by the book lies in the gap between these two carefully paired essays - in much the same way that Etienne Balibar has suggested that the 'fecundity' of Althusser's 'Ideological State Apparatuses' essay derives from the 'suspension of the argument in the vicinity of the decisive articulation' between 'two fundamentally discontinuous series of arguments' ${ }^{8}$ There is a kind of formal sleight of hand whereby, being placed next to each other, the two series appear to enter into a relation, despite the fact there no theoretical development actually occurs mediating the two. The prospect of an integral theoretical position is thus gestured towards, but remains frustratingly out of view.

\section{Learning from fascism}


Bloch's 'Summary Transition' is the fifty-page middle section of the central part of Inheritance of This Time, on 'Non-sametimeliness and Intoxication' (Berauschung). It thus stands at the very centre of the book, indeed, is its 'orientating centre', in Bloch's words from his 1934 Preface. Most relevant here is what by the 1962 edition had become the third of five parts of this 'orientating centre', 'Nonsametimeliness and Sametimeliness, Philosophically' (Ungleichzeitigkeit und Gleichzeitigkeit, philosophisch): a fifteen-page passage at the centre of the orientating centre that concludes with a section entitled 'Problem of a Multi-Layered Dialectic'. This problem is both outlined and also finds the schema of its solution there, in a Leninist account of 'proletarian hegemony', which takes as its slogan:

no proletarian hegemony... without thoroughly 'mastering' the substance of genuine non-sametimeliness (Ungleichzeitigkeit) and its heterogeneous contradictions. $^{9}$

This is the political moral of the early Bloch's writing on time, of which Tomba's book may be read as an insistent reminder. However, not only is this condition of proletarian hegemony a negative (and hence insufficient one) one - 'no proletarian hegemony without...' - but it was already in 1935 historically belated as political advice. It was directed at the conditions under which the book was composed (the rise of fascism in Germany in the early 1930s), as a prospective reversal of those conditions, through a Left appropriation of the temporal strategy that had brought them about: a 'learning from fascism', not unlike the 'Learning from Thatcherism' that Stuart Hall would subsequently propose in the $1980 \mathrm{~s} .{ }^{10}$ Or more precisely, as Frederic Schwartz puts it in his wonderful article, 'Ernst Bloch and Wilhelm Pinder: Out of Synch' (from which I have stolen my title), the idea was to counter the 'brown theft' of communist rhetoric by fascism, with the 'red theft' of fascism's political 
exploitation of 'non-sametimely' social elements and cultural strata. ${ }^{11}$ Yet, by 1935 , even if such a project made theoretical sense (as the temporalized basis of a Popular Front), in Germany it was already too late. The significance of Bloch's intervention thus became that of a general theoretical lesson, equally applicable elsewhere (to the historical conditions in the Soviet Union at the time, for example, although that could not be said) - indeed, anywhere else, insofar as the analysis can justify its claim to being a specifically 'philosophical' one; that is, can justify the assumption that such a formal reversal of the political polarity of such a temporal strategy makes enduring historical - rather than merely short-term, tactical - sense.

This is a fundamental problem in the philosophy of historical temporalizations. It raises the issue: just how applicable is Bloch's analysis today? Is it especially applicable, in the radically interconnected and evermore developmentally 'unequal' world of global capital, as Tomba implicitly suggests? Or are there limits derived from the historical context of its formulation? And, to the extent that it is not applicable, what does this tell us about the temporalities of history today; and the forms of politics they render possible? ${ }^{12}$ This is the context of problems into which Tomba's reading of Marx is pitched by its appropriation of Bloch's concept of temporal layers. They are exaccerbated by the mediation of this reception via Koselleck, since it is not clear that the generalized Koselleckian framework is compatible with Tomba's emabrace of Bloch's broadly Leninist temporal-political project (hegemony). One set of clues to the theoretical complexity of this context lies in the multiple English translations of Bloch's central conceptual opposition of Gleichzeitigkeit and Ungleichzeitigkeit.

To date there have been three equally problematic alternatives: (1) 'synchronicity/non-synchronicity', (2) 'simultaneity/non-simultaneity' and (3) - the 
truly sympotomatic one, used by Neville and Steven Plaice, in the 1991 Polity edition, Heritage of Our Times - 'contemporaneity/non-contemporaneity'. ${ }^{13}$ These are not merely alternative possible translations of Bloch's terms, but conceptually radically different proposals, which overdetermine the philosophical meaning of Bloch's text in relation to subsequent theoretical and historical contexts, in different ways. In brief, (1) as a strictly structural temporality (this is Tomba's choice in his displacement of the idea onto the plurality of temporalities of capital), (2) naturalistically, according to the structure of physical or 'cosmological' time; and (3) in accord with the more complex cultural and now-historical temporality of the living actuality of the present, characterized by conjunction and disjunction (disjunctive synthesis), which entered critical debates only in the last three decades ('after 1989'). ${ }^{14}$ The awkwardly literal 'sametimeness', on the other hand, (my stubborn fourth option) evokes Kierkegaard's Danish samtidiged, philosophical source of the existential idea of the act of bringing together different times to produce a 'same time'. It is this Kierkegaardian 'sametimeness', I have argued elsewhere, that first exhibits at the level of the individual, the structure of 'contemporaneity' subsequently to emerge, over one hundred years later, as a genuinely historical form. ${ }^{15}$ Critically, it is this notion of an active production of sametimessness (to each act its own production of time) that raises serious questions about the essentially reactive character of Tomba's notion of multi-temporality as the mere 'occasion' of political intervention. Bloch's Leninism appears here, in Tomba, in late or post-Althusserian, occasionalist guise: 'conjuncture' is coded in aleatory fashion as 'occasion'. ${ }^{16}$

Significantly, the 'simultaneity' and 'synchronicity' translation options have their own literal equivalents in German (Simultaneität and Synchronität), while translating back in this directiom, 'contemporaneity' has no satisfactory German equivalent ${ }^{17}-$ 
the closest probably being the awkward neologism, Zeitgenossenschaflichkeit. Gleichzeitigkeit itself, and a gloss on 'presentness', Farbigkeit auch etwas Gegenwärtiges (could one say Gegenwärtigkeit?), are currently the most commonly used ways to translate 'contemporaneity' into German. However, along with Zeitgenossenschaflichkeit, both etymologically and in their historical-semantics, they fail to convey what is most central to the notion: namely, a sense of the distinctive temporality of the 'with' (con-), of a coming together of multiple and hence different times. To understand the deeper conceptual meaning and political possibilities of Bloch's Ungleichzeitigkeit one must thus read it from the standpoint of Kierkegaard's samtidiged, as the mark of historically different but coeval temporalities that can be brought together in different ways within the present: through the 'mastering' of their 'heterogeneous contradictions'. ${ }^{18}$

The historically differential temporal multiplicity of non-sametimeness (what Bloch called an 'infinitely many-voiced' past ${ }^{19}$ is the issue at the forefront of the conceptual structure of 'contemporaneity' today, in its relations to the 'plurality' of temporalities of capital. The latter appear, from a Blochian standpoint, on a historically common temporal plane. Yet capital appears to us, today, as itself historically differential. What appears in the Plaices' translation as 'noncontemporaneity' is thus, ironically, the precise structure of contemporaneity itself today. A wide variety of commentators have recognised Bloch as the precursor of current debates about historical temporality. What has gone unrecognised is that he is so in an inverted form: Bloch's 'non-sametimeliness' is the very structure of the 'sametimeliness' produced by capital today. Synchronization by global markets produces not just social homogenization but also the differentiation of historically specific localities, which find themselves related to one another for the first time. As 
Appaduri has argued: today, locality is the product of global relations (Appaduri, 2013).

This inversion registers an element of what Bloch himself called 'genuine pastness' in Bloch's own text: namely, its internalization of the plural temporalities of capital itself to a single historical plane.

In Tomba's book, there is no sense of this inversion of terms imposed on Bloch's text by the recent global history of capitalism, or of there being any 'genuinely' passed or 'exhausted' elements within it. Tomba appears driven by the political imaginary of a post-Trotskyist revival of Bloch's Leninism ('no proletarian hegemony without...') rather than by the new theoretical and political possibilities opened up by a historical judgment on the limitations of Bloch's text. Yet in Tomba's own account, the articulating moment of unity, posited by Bloch as 'hegemony', appears only structurally, as the product of the syncronization of the world market. As a result, politics is displaced from hegemonic articulation onto political reactions to 'occasional' contradictions between synchronized and non-synchronized social elements.

Theoretically, the limitations of Bloch's book are to be found in the very same place that its current admirers locate its timeliness: namely, in its geological imaginary of temporal layering, which confines temporal multiplicity, once again, to the historicist framework of developmentalism. In Bloch's book, this developmentalism, derived from Marx, and existing on the geographically singular plane of 'history', co-exists in tension with the more complicated idea of 'a multitemporal and multi-spatial dialectic', which problematizes the spatial ground of historical totalization. ${ }^{20}$ Yet rather that taking up the multi-spatial aspect of this idea, Tomba, following the currently dominant reception of the book, turns to Koselleck's 
generalization of its temporal component alone. This dates back to Koselleck's 1973 essay 'History, Histories and Formal Structures of Time', in which the 'sametimeness of the non-sametimed' - Gleichzeitigkeit der Ungleichzeitigen - appears as the 'prognostic structure' of one of the 'three modes of temporal experience' that define historical experience as such. (Koselleck fails to mention Bloch's name in this formal exposition of the concept - the political abomination to him of Inheritance of This Time presumably being too much for him to acknolwedge it.) The geologically regulated spatialization of the 'non-sametimed' as temporal layers, subsequently set out in the 1995 essay 'Zeitschichten', is similarly reticient about its source.

This is not the occasion for an analysis of either Bloch's or Koselleck's productive but profoundly problematic texts. Suffice to say, Tomba's innovation is transpose the analysis to the history of capitalism by positing the capitalist market as the syncronizing agent, or producer of sametimeness. The 'layered historiography' of Marx's pre-history of capitalism is thereby integrated into the global capitalist present as a distinct set of temporal relations, in which the conventionally stagist distinction between formal and real subsumption to capital is triangulated with Marx's political notion of hybrid subsumption, to produce a structural analysis of historically differential forms of subsumption within the present. It is the relations between these historically different, or multiple, temporalities that are understood to provide the 'political occasion for intervention'. However, having displaced articulation from hegemony to market synchronization, there is aporia of the temporal position of the political agent here. From within which time(s) does the political agent/subject of politics act?

This was already a serious problem in Bloch's account, since, in the absence of what he called 'subjectively sametimely contradictions' capable of 'activating' 
objectively sametimely ones (the classical revolutionary scenario), the proletarian hegemonic agent was understood to act only via its re-articulation of (subjectively and objectively) non-sametimely contradictions with objectively sametimely ones. Whilest these non-sametimely contradictions themeselves were seen to be capable of shedding their 'reactionary' political character, only is this way. However, this scenario abstracts the hegemonic agent itself from historical temporality, making it the external 'master' of a multiplicity of which it is, in fact, a part. In the postAlthusserian context of Tomba's book (theoretically legitimated there somewhat awkwardlky via Benjamin), this aporetic externality is ontologized, in the identification of political actions as events. The aleatory temporality of the 'occasion' alone connects structure to event. But the connection is purely formal. Those temporalities that are divergent from or conflicting with the process of synchronization do not seem capable of forms of political agency that can structurally transform that synchronization itself. The temporal aporia is at the same time an aporia of the political subject. Acts are considered to take place within particular temporalities, and as articulations of different temporalities, but not as being productive of their own temporalities, and hence their own new synchronizations.

Tomba convincingly places Marx's writings firmly within the framework of the philosophy of time, and he brings to them there certain decisive theoretical innovations from the 1930s and the 1960s. These innovations move us closer to being able to theorize the temporal complexities of our historical present, but they are stopped short by the growing exhaustion as those pasts themselves.

\section{References}


Appaduri, Arjun 2013, 'How Histories Make Geographies: Circulation and Context in a Global Perspective', in The Future as Cultural Fact: Essays on the Global Condition, London and New York: Verso, 61-9.

Balibar, Etienne 2014, 'Foreword: Althusser and the "Ideological State Apparatuses", in Louis Althusser, On the Reproduction of Capitalism, translated by G. M. Goshgarian, London and New York: Verso, vii-xviii.

Bhabha, Homi, The Location of Culture, London and New York: Routledge, 1994

Bloch, Ernst 1985, Erbschaft dieser Zeit (1935; 1965), Frankfurt-am-main: Suhrkamp, 1985.

1977 'Nonsynchronism and the Obligation to its Dialectics' (1932), translated by Mark Ritter, New German Critique 11, 22-38.

1991, Heritage of Our Times (1935; 1962), translated by Neville and Stephen Plaice, Cambridge: Polity Press.

Durst, David C., 2002, 'Ernst Bloch's Theory of Nonsimultaneity' The Germanic Review: Literature, Culture, Theory, 77: 3, 171-94.

Hall, Stuart 1988, The Hard Road to Renewal: Thatcherism and the Crisis of the Left, London and New York: Verso.

Harootunian, Harry 2000, Overcome by Modernity: History, Culture, and Community in Interwar Japan, Princeton and Oxford: Princeton University Press.

----------- 2007, 'Remembering the Historical Present', Critical Inquiry 33: 3, 471-94.

Jameson, Fredric 1991, Postmodernism, or, the Cultural Logic of Late Capitalism, London and New York: Verso

Koselleck, Reinhart 1985, 'History, Histories and Formal Structures of Time' (1973), in Futures Past: On the Semantics of Historical Time, translated by Keith Tribe, Cambridge MA and London: MIT Press.j

2000, 'Zeitschichten' (1995), in Zeitschichten: Studien zur Historik, Frankfurt-am: Suhrkamp.

2002, 'The Unknown Future and the Art of Prognosis', in The Practice of Conceptual History: Timing History, Spacing Concepts, translated by Todd Samuel Presner etal, Stanford: University of Stanford Press, 131-47.

Osborne, Peter 1995, The Politics of Time: Modernity and Avant-Garde, London and New York: Verso.

2008, 'Marx and the Philosophy of Time', Radical Philosophy 47 (Jan/Feb 2008) 15-22.

2009, 'Occasionalism', in Matias Faldbakken: Shocked into Abstraction, 
National Museum of Art, Architecture and Design, Oslo/Ikon Gallery, Birmingham, 44-71.

2013a, Anywhere Or Not At All: Philosophy of Contemporary Art, London and New York: Verso.

2013b, 'Global Modernity and the Contemporary: Two Categories of the Philosophy of Historical Time', in Chris Lorenz and Bevernage, eds, Breaking Up

Time: Negotiating the Borders Between the Present, the Past and the Future, Göttingen: Vandenhoeck and Ruprecht, 69-84.

2014, 'The Postconceptual Condition, Or, the Cultural Logic of High Capitalism Today’, Radical Philosophy 184 (March/April 2014), 19-27.

Postone, Moishe 1993, Time, Labour and Social Domination: A Reinterpretation of Marx's Critical Theory, Cambridge: Cambridge University Press.

Schwartz, Frederic J 2001, 'Ernst Bloch and Wilhelm Pinder: Out of Sync', Grey Room 3, 54-89.

Tomba, Massilmilliano 2013, Marx's Temporalities, translated by Peter D. Thomas and Sara R. Ferris, Leiden and Boston: Brill.

Tombazos, Stavros 2014, Time in Marx: The Categories of Time in Marx's Capital (1994), translated by Christakis Georgiou, Leiden and Boston: Brill.

\section{Notes}

${ }^{1}$ Postone 1993; Tombazos 2014.

${ }^{2}$ Tomba 2013, 92-158, 136.

${ }^{3}$ See Osborne 2008 and 1995. The ontological primacy of temporality over time is the main philoosphical contribution of Heidegger's 1928 Being and Time.

4 Tomba 2013, 137.

${ }^{5}$ Tomba 2013, xiii- xiv.

${ }^{6}$ Tomba 2013, 137.

${ }^{7}$ Tombazos 2014. While Tomba relies on Tombazos's commentary for a large part of his framework, no reference is made to Postone's theoretically more innovative 1993 work, with its categories of 'abstract time' and 'abstract domination'. Tomba wants to maintain an orthodox combination of a capital-based analysis with a class-based politics of precisely the kind that Postone's interpretation of the abstract form of the domination of capital throws into doubt.

${ }^{8}$ Balibar 2014, xii-iii.

${ }^{9}$ Bloch 1991, 114.

${ }^{10}$ Hall 1988, 271-83.

${ }^{11}$ Schwartz 2001, 79.

${ }^{12}$ See, for example, Jameson 1991, 302-13; Bhabha 1994, 192-9 and 217-9. For a more orthodox application, see Harootunian 2000, xvii and 216; Harootunian 2007.

${ }^{13}$ Bloch, 1977; Durst, 2002; Bloch 1991.

${ }^{14}$ See Osborne 2013a, Ch.1 and 2013b. 
${ }^{15}$ Cf. Osborne 2014, 23-4.

${ }^{16}$ This is basically a theological trope, which comes to take on an aesthetic form as part of the temporal experience of modern. See Osborne 2009, 59-69.

${ }^{17}$ Osborne 2014, 27, n26.

${ }^{18}$ Bloch 1991, 114.

${ }^{19}$ Bloch 1991, 114.

${ }^{20}$ Bloch 1991, 115. 